UDC 94(477.82):792.07-054.7

DOI: 10.24919/2519-058x.15.204967

\title{
Ruslana DAVYDYUK
}

PhD hab. (History), Associate Professor, Professor, Rivne State Humanities University, 12 Stepan Bandera Street, Rivne, Ukraine, postal code 33000 (davrus63@gmail.com)

ORCID: https://orcid.org/0000-0003-0485-5121

\section{Andriy ZHYVYUK}

PhD (History), Associate Professor, Professor at Stepan Demianchuk International University of Economics and Humanities, 4 Stepan Demianchuk Street, Rivne, Ukraine, postal code33000(derzhy60@gmail.com)

ORCID: https://orcid.org/0000-0002-9031-880X

\section{Руслана ДАВИДЮК}

доктор історичних наук, професор, професор Рівненського державного гуманітарного університету, вул. Степана Бандери, 12, м. Рівне, Украӥна, індекс 33000 (davrus63@gmail.com)

\section{Андрій ЖИВ'ЮК}

кандидат історичних наук, доиент, професор Міжнародного економіко-гуманітарного університету імені академіка Степана Дем'янчука, вул. Степана Дем'янчука, 4, м. Рівне, Україна, індекс 33000 (derzhy60@gmail.com)

Бібліографічний опис статті: Davydyuk, R. \& Zhyvyuk, A. (2020). Theater art as a self-realization form of Naddnipryanshchyna political emigrants in Volyn Voivodeship (1920 1930-ies). Skhidnoievropeiskyi Istorychnyi Visnyk [East European Historical Bulletin], 15, 128-135. doi: 10.24919/2519-058x.15.204967

\section{THEATER ART AS A SELF-REALIZATION FORM OF NADDNIPRYANSHCHYNA POLITICAL EMIGRANTS IN VOLYN VOIVODESHIP (1920 - 1930-ies)}

\begin{abstract}
The purpose of the article is to analyze the Dnieper (Naddnipryanshchyna) political emigrants' influence on the Western Volyn region theatrical life: from the mobile theater troupes spread to the VUT creation, which facilitated their adaptation and promoted creative self-realization. The methodology of the research is based on the historical, cultural chronological methods, as well as the analysis and systematization methods, which made it possible to consider Volyn Ukrainian Theater mobile troupes appearance conditions, to trace their relations with the Polish authorities, the repertoire features and the importance of creativity for the national consciousness of the local Ukrainian population. The prosopography method was applied in order to find out the artists' names. The scientific novelty of the article is the introduction to the scientific circulation of the new archival documents, the interwar periodicals, which made it possible to show the Dnieper (Naddnipryanshchyna) political emigrants' influence on the interwar Volyn theatrical life development. The Conclusions. The Ukrainian political emigrants became fully involved in the cultural and artistic activities, realized their talents and skills in the theater and amateur work, after the revolution defeat of 1917 - 1921 in
\end{abstract}


the territory of Volyn Voivodeship. In the first half of the 1920-ies, mobile theaters became a means of embodying the creative aspirations of the artists and the golden opportunity to earn a living. The commencement of the "Volyn experiment" by voivode H. Yuzevskyi, M. Pevnyi's and other artists, who came from Naddnipryanshchyna relocation to Lutsk caused the VUT establishment, which during the 1930-ies of the XXth century kept the national spirit, Ukrainian traditions, the way of life and culture. The establishment of Bolshevik power in the region in 1939 led to the total control over the cultural life of the region, including the theatrical arts.

Key words: mobile theater troupes, Volyn Ukrainian Theater, Ukrainian political emigrants, Volyn Voivodeship, Second Polish Republic.

\title{
ТЕАТРАЛЬНЕ МИСТЕЦТВО ЯК ФОРМА САМОРЕАЛІЗАЦЇ̈ НАДДНІПРЯНСЬКИХ ПОЛІТИЧНИХ ЕМІГРАНТІВ У ВОЛИНСЬКОМУ ВОСВОДСТВІ (1920 - 1930-ті рр.)
}

\begin{abstract}
Анотація. Мета дослідження. У статті проаналізовано місце $i$ роль міжвоєнної української політичної еміграції у театральному житті Волинського воєводства. Доведено, що, незважсаючи на побутові труднощі, емігранти вирізнялися громадсько-політичною та соиіокультурною активністю, а театральна діяльність була як способом заробітку, так і можливістю творчої самореалізації. Методологія дослідження базується на історикокультурному, хронологічному методах, а також методах аналізу і систематизачї, що дозволило розглянути умови появи мандрівних труп, Волинського українського театру, прослідкувати їх взаємини з польською владою, особливості репертуару та значення творчості для національної самосвідомості місиевого украӥнського населення. Метод просопографії знадобився для з'ясування імен артистів. Наукова новизна статті полягає у введенні до наукового обігу нових архівних документів, міжвоснної періодики, що дало можливість показати вплив наддніпрянських політичних емігрантів на розвиток театрального життя міжвоєнної Волині. Висновки. 3 ініціативи діячів украӥнської революиї̈ 1917 - 1921 рр., що змушені були емігрувати на територію Другої Речі Посполитої і поселилися у Волинському воєводстві, значно активізувалася театральна діяльність, яка у 20-х роках акумулювалася у поширенні мандрівних театральних труп, гуртків при товаристві "Просвіта", а у 30-х роках виявилася у створенні та діяльності Волинського украӥнського театру. Цей період ознаменований неоднозначним ставленням польської влади до українського театру, формуванням репертуару, поширенням української вистави у віддалених куточках регіону.
\end{abstract}

Ключові слова: мандрівні театральні трупи, Волинський украйнський театр, украйнські політичні емігранти, Волинське воєводство, Друга Річ Посполита.

The Problem Statement. Owing to the Bolshevik tookover of power and the Ukrainian National Democratic Revolution defeat in 1917 - 1921, the Ukrainian political emigration emerged. Numerous military and civilian emigrants moved to the interwar Poland. After gaining their artistic experience in the internment camps, they activated the theatrical life in Volyn Voivodeship and created a number of the mobile theatrical troupes. The Polish authorities caused difficulties and obstacles for the Ukrainians theatrical life, forbidding the plays' production, controlling the repertoire. At the same time, the Dnieper region theatrical figures established Volyn Ukrainian Theater (VUT), which defined the artistic development of the region in the 1930-ies.

The purpose of the article is to analyze the Dnieper (Naddnipryanshchyna) political emigrants' influence on the Western Volyn region theatrical life: from the mobile theater troupes spread to the VUT creation, which facilitated their adaptation and promoted creative self-realization.

The Analysis of the Recent Researches. There are diverse academic researches dedicated to the coryphaeus (luminaries) of Ukrainian theater and the organizers of the 
theatrical affair in Ukraine, but the interwar theater life history during the interwar Volyn, and even more the Dnieper peoples' involvement, remains unresearched in the contemporary historiography. In the first informative publication on the emigrants' cultural work written by Symon Narizhnyi, their activity in Volyn Voivodeship is mentioned briefly (Narizhnyi, 1942). Some theatrical life details are described in the following edition: "Our Theater. A Book of Ukrainian Theater Art Figures of 1915 - 1991", two volumes of which were edited by the literary critic Hryhor Luzhnytskyi (Luzhnytskyi, 1975), but there is also little material on Western Volyn. The theatrical life in Volyn Voivodeship is reflected in some works written by modern Ukrainian scholars, including Olena Bonkovska, who studied the theater in Western Ukrainian lands (Bonkovska, 2008), Volyn Ukrainian Theater (VUT) was studied by Sophia Stepaniuk (Stepaniuk, 2008), Ruslana Davydiuk dealt with the Dnieper emigrant' socio-cultural practices (Davydiuk, 2016) and the others. The specifics of the theatrical art development in the interwar Volyn, as well as the Ukrainian political emigrants' importance in this process, remains insufficiently researched, the source base of the article was mainly the archival documents and the interwar periodical press materials.

The Statement of the Basic Material. The theater has always been an integral part of the social, cultural and artistic life of the society. In the 1920-ies, the amateur theater movement in Volyn Voivodeship was associated with "Prosvita" musical and dramatic sections activities, as well as with the travelling theater troupes proliferation. Petro Zadorozhnyi-Zadonskyi, the Naddnieper worked as Kovel's "Prosvita" artist-director. In 1922, the emigrant Viktor Staroschuk (theatrical alias Dolnyi), who performed in amateur groups and Mykola Sadovskyi's theater, returned to the theatrical life. During the UNR Army retreat, he stayed in Rivne, then moved to Lutsk, where in January 1927 he headed the "Ukrainian Artists Society" at the local "Prosvita".

The founder of the dramatic group at Ostroh "Prosvita", the emigrant Mykola Shuhayevskyi, staged plays by Ukrainian authors and wrote his own plays. There were the directors' courses in Rivne "Prosvita". Petro Zinchenko, the Naddnieper, whose graduates were in charge of the drama clubs in the villages and towns of the county, was conducting the lessons. There were even the theater group, the choir, the string orchestra in the UNR Army's internment camp, the labour settlement was located at the sugar plantations of Babyn village, Rivne povit (district) and was headed by Yevhen Biletskyi, the UNR Army General-Chorister. The performances and concerts served not only the leisure time activity but also made it possible to obtain funds for the needs of immigrants, replenish the cash aid (Samoorhanizatsiia ta hromadske zhyttia ukrainskoi emihratsii v Polshchi, 1926, pp. 13-14).

Volodymyr Savchenko-Bilskyi, the UNR Army General-Cornet (General-Khorunzhyi) never abandoned his admiration - theater, that's why, he organized numerous Ukrainian plays in Sarny. Andriy Dubynovskyi, ataman's Volodymyr Oskilko former adjutant, having some experience in theater management in internment camps, arranged the drama groups in the villages near Rivne. (Sectoral State Archive of the Security Service of Ukraine (SSA SSU, Rivne), f. 5 (R), d. 1, c. 5219, p. 43). In general, the level of the amateur theater group's development depended on the activity and creative desires of the initiators of such groups.

The mobile amateur troupes, which were established by the emigrants from the Dnieper Ukraine (Naddnipryanshchyna) were the most widespread form of the theatrical life during the 1920-ies. The artistic level of these groups was low, as there were few professional actors there. At the same time, such a mobile form of the theatrical practice led to the Ukrainian word spreading even in the remote villages of the region, and also made it possible to earn a living for the troupes. 
The teams, which consisted of 15-40 people carried on the process of changing the actors, the directors, who moved from one troupe to another. This, on the one hand, deepened the artists' mutual influence, but on the other hand, indicated the complexity of the conditions and the difficulty of the activity. The actors were forced to sew costumes on their own, to draw scenery for unpretentious household scenes. It was required to receive the concession in the voivodship or in 'starostvo' (the village elder) in order to organise a troupe. As a result, the concessionaire was appointed as the theater director. Such permission gave the opportunity to work in the territory of the respective administrative unit (Luzhnytskyi (red.), 1975, p. 14).

After the the UNR State Drama Theater evacuation from Kamianets-Podilskyi city, the part of the actors settled down in the Western Ukrainian lands, hence, becoming the part of the Second Polish Republic (Second Commonwealth). In the summer of 1921 the renowned director Oleksandr Zaharov moved to Lutsk, but after a few months, due to the "Ukrainian Conversation Society" invitation, he moved to Halychyna (Galicia) with his wife, performer Maria Morska. (Luzhnytskyi (red.), 1975, pp. 22-23).

In 1920 the actors, who came from Naddnipryanshchyna (the Dnieper Ukraine) organized a theater in Kovel, which was headed by Theodora Rudenko. In May 1922, this troupe was reorganized into the Ukrainian Naddnipryanshchyna (Dnieper) Theater. The theater was increasing quantitatively and organizationally, that's why the artists performed in Polish various cities. The troupe composition remained stable for a long time, the natives from Kyiv region: Theodora Rudenko and her husband Nazar Obidzinskyi created the theater's nucleus. Nazar Obidzinskyi was in charge of the administrative work. Agatha AndriyivaLubska, T. Rudenko's mother and a native of Kamianets-Podilskyi gained considerable popularity as the performer (State Archives of Rivne region) (SARR), f. 30, d. 2, c. 557, p. 4). Travelling, the theater staged mostly historical, folk performances (Desiata richnytsia isnuvannia Ukrainskoho Naddniprianskoho Teatru u Polshchi, 1932, pp. 25-26).

The Ukrainian Naddnipryanshchyna (Dnieper) Theater under Olha Mitkevych's guidance, which was established in the internment camps, continued its activity in Volyn. The Ukrainian Naddnipryanshchyna (Dnieper) Theater also toured around Poland. Subsequently, a troupe led by Nina Boyko emerged from this team (SARR, f. 156, d. 2, c. 167, p. 22).

Mykola Aydariv, an actor at the UNR branch State Theater in Mohylov, a native of Kharkiv, founded the "Renaissance" ("Vidrodzhennia") Theater in Lutsk in 1922, having broken away from the I. Kogutyak's Ukrainian Movable Drama Theater (created in 1920 in Stanislaviv and supplemented by M. Sadovskyi's Theater actors) (Luzhnytskyi (red.), 1975, p. 22; Narizhnyi, 1942, p. 312). There were numerous actors in the Renaissance Theater troupes, in particular, the M. Aydariv's wife Maria; Opanas Karabynevych, a native of Vinnytsia, who worked at the internment camp in Czestochowa; Yuriy Kononov, a native of Kyiv, the UNR Army centurion and an actor at the Shypyorno Camp Theater (Kononiv, 1992, p. 713) and the others. M. Aydariv's troupe was also travelling with the Ukrainian-language performances, staging historical and domestic character plays (Hastroli trupy Poltavchanka, 1932, pp. 22-23).

Mykola Komarovskyi's, Hryhoriy Berezovskyi's theatrical collectives worked in the Voivodeship fruitfully. The theater "Ray" ("Promin") under Mykola Komarovskyi's guidance staged the following performances: "Night on Ivan Kupal" written by M. Starytskyi, "Zaporozhets by the Danube" written by S. Hulak-Artemovskyi and the others. In February 1924, there were 11 artists in the above-mentioned theater troupe (SARR, f. 30, d. 2, c. 557, p. 17 v). In 1928 H. Berezovskyi, a former actor and the director of M. Sadovskyi's theater 
in Katerynoslav and his wife Marta Avsyukevych-Berezovskyi headed the dramatic circle at "Prosvita" in Kremenetsk. Actually, H. Berezovskyi invented and was the first, who applied the light effects in the theatrical practice (Yuvilei artysta Berezovskoho, 1935, p. 6).

Mykola Orel-Stepnyak, the People's Theater director of "Prosvita" in Lviv, having lost his concession to the theater activity in the Eastern Galicia (Halychyna), moved to Volyn in May 1926. He established the theater bureau at Lutsk "Prosvita" and later organized a theater (State Archives of Ivano-Frankivsk Region (SAIFR), f. 2, d. 1, c. 597, p. 38). Naddnipryanshchyna wandering theaters under I. Horodnychoho-Ohorodnykova and R. Buhayov-Poltavchenko guidance travelled with the performances on everyday and historical subjects through Volyn Voivodeship villages. (Hastroli trupy Poltavchanka, 1932, p. 6).

The Polish authorities controlled the theatrical troupes' performances, carried out the systematic inspections and imposed bans. In Volodymyr povit the village elders even checked A. Karabinevich's travelling troupe artists' documents. The result was the eviction of two artists, who came from Naddnipryanshchyna -one actor was sent to Kalish, the other to Ternopil. The Ukrainian Central Committee Attempts to protect the artists were futile, only after the personal appeal to the voivode, the eviction decision was overturned. However, after the tour was over, the police continued to conduct searches at the local Ukrainian activists' homes (Volodymyrivshchyna, 1928, p. 4).

During the first interwar decade, despite its successes, the Ukrainian theatrical troupes were smaller than the corpses of other nationalities, which is explained by both the government policy and the material difficulties. In addition, the Polish administration tried to isolate Volyn's cultural space from Galicia's influences. The main opposer of such a policy was Volyn Voivode Henryk Yuzevskyi, who was consistently implementing the idea of the "Sokal Border" (Davydiuk, 2016, p. 516).

The number of travelling troupes decreased after the VUT establishment. The VUT was headed by Mykola Pevnyi, a native of Poltava region, the UNR Army centurion. After receiving his theater education at Raihoff's drama courses in Petrograd, before the revolution, he worked in various theater troupes, later on, organized an amateur group at the Kalish internment camp. The VUT foundation day is considered to be on the 18th of November in 1928 when at the 10th-anniversary celebration dedicated to Lutsk "Prosvita", the actors played an act of the historical play, which was called "Hetman Doroshenko" written by L. Starytska in the city theater (Stepaniuk, 2008, pp. 320, 325). The composition of the theater remained stable for a long time, up to 25 artists, increasing to 30 people in 1939. The peasants were the main contingent of the audience, so the prices for performances were low - varied from $50 \mathrm{hr}$. up to $1 \mathrm{zl} .50 \mathrm{hr}$. (Pevnyi, 1936, p. 2). The artists' financial situation was not easy: because of the low pay for the performances, they often had to look for the additional earnings (Staryi teatral, 1929, p. 3).

In Lutsk at the village elders (starosta) conference, the financial assistance to the theaters was discussed on the $4^{\text {th }}$ of November in1931. Voevoda Yuzevskyi noted that the Ukrainian theater can apply for "certain quotas" only if the "state center" value is acquired. At the same time, more categorical opinions were heard at this conference: Dubenskyi headmaster assured that it was necessary to "limit the influx of foreign Ukrainian theaters to Volyn" (State Archives of Ternopol region (SATR), f. 2, d. 3, c. 59, p. 2 v). However, the VUT had the authorities' support, for example, Volyn Voivodship Administration Self-Government Department allocated about 18 thousand PLN for the needs of the theater annually (State Archive of Volyn Region (SAVR), f. 200, d. 1, c. 2, p. 57). In 1935, the Ministry for Religion and Public Education allocated 1 thousand zł. monthly grants for the theater (SARR, f. 478, 
d. 1 , c. 3 , p. $30 \mathrm{v}$ ). However, these funds were not enough, so the theater tried to make money on its own.

Traditionally, VUT dated performances to the prominent Ukrainian historical dates or individuals. The critics and the public have been uneasy about the theater's repertoire based on the domestic plays. The artists staged the following performances: "Sorochinskyi Yarmarok (Fair)", "Natalka Poltavka", "Christmas Night", "Oy Ne Khody, Hrytsyu”, "Martyn Borulya" and the others. There were some thoughts concerning to revise the repertoire, to eliminate the "hoppachyna"(Buty chy ne buty, 1936, p. 3). M. Pevnyi explained: "We have a repertoire with which the easiest way to approach the soul of a Ukrainian peasant, that is, household and historical" (Zahalni zbory teatralnoho tovarystva, 1939, p. 5). However, in some places the theater also resorted to the European repertoire. On the $21^{\text {st }}$ of November in 1937 the comedy "Dark Spot" written by M. Kadelburg was played for three acts in Lutsk (O. K., 1937, p. 4).

VUT often travelled, usually starting the theatrical season in September with a play at "Ridna Khata" premises in Lutsk. During the 6-month "Volyn" tour, from December 24, 1936 to June 28, 1937, the theater visited 6 counties, staged 133 performances, which were attended by 27226 spectators. (Podorozh Volynskoho Ukrainskoho teatru po Volyni, 1937, p. 3). It was quite difficult to tour, as the troupe actors e had to carry even the smallest things with them. Sometimes they travelled by trains, by cars, but mostly by water because of the poor roads' conditions and the cheapness of this type of transport.

Volyn Ukrainian Theater Society (VUTS) took care of the theater, the founding meeting of which was held in Lutsk on January 3, 1932 on the basis of the statute approved on November 7, 1931. (SAVR, f. 200, d. 1, c. 2, p. 53). VUTT brought together the representatives of the Ukrainian intelligentsia, who were not indifferent to the theatrical and musical arts. The Board of Directors of the Society consisted mainly of Naddnipryanshchyna natives emigrants: Mykola Maslov was the Chairman, Oleksandr Kovalevskyi was the Deputy, Oleksa Almazov was the Treasurer. The members of the Board were Vasyl Halushka, Teodor Lovetskyi, Mykhailo Tyravskyi, and the others (SAVR, f. 200, d. 1, c. 1, pp. 7, 16).

During the second half of the 1930-ies, separate amateur groups continued their activity in Volyn Voivodeship. Among other ascetics, there also was Vitaliy Yurchenko, who in 1930 managed to escape from the Solovetskyi camps and settled down in Lviv. After he moved to Volyn in 1936, he worked in Korets, Rivne, Zdolbuniv, took the floor with abstracts, substantiating the role of the theater in the national consciousness development. His practical activity as the head of a drum club in Zdolbuniv was successful. In the povit amateur collectives" competition, the drama circle, which stagged the play-satire "Generalna Proba" ("General Trial") written by Yurchenko, received a diploma of the 1st degree (Konkurs dramatychnykh hurtkiv na Zdolbunivshchyni, 1939, p. 3).

In 1939 the Bolshevik's power establishment in the Western Ukraine territory in September caused a fundamentally different situation for the theatrical art development. The People's Commissariat of Internal Affairs (NKVD) bodies purged the personnel, fired the "alien people", and the Soviet Ukraine theaters artists' involvement led to the total control establishment over the cultural life of the region, including the theatrical art (Zhyviuk, 2011, p. 29). At that time, many former artists left the Bolshevik-controlled territory, and many were arrested. Mykola Pevnyi's fate remains unknown, VUT director, quite possibly that he was shot in Bykivnia.

The Conclusions. The Ukrainian political emigrants became fully involved in the cultural and artistic activities, realized their talents and skills in the theater and amateur 
work, after the revolution defeat of 1917 - 1921 in the territory of Volyn Voivodeship. In the first half of the 1920-ies, mobile theaters became a means of embodying the creative aspirations of the artists and the golden opportunity to earn a living. The commencement of the "Volyn experiment" by voivode H. Yuzevskyi, M. Pevnyi's and other artists, who came from Naddnipryanshchyna relocation to Lutsk caused the VUT establishment, which during the 1930-ies of the XXth century kept the national spirit, Ukrainian traditions, the way of life and culture. The establishment of Bolshevik power in the region in 1939 led to the total control over the cultural life of the region, including the theatrical arts.

Acknowledgements. We would like to express our gratitude to the staff of the archival institutions whose documents were used in the article, the editorial board members for the given advice during the preparation of the article for publishing.

Funding. The authors received no financial support for the research, authorship, and/or publication of this article.

\section{BIBLIOGRAPHY}

Bonkovska, O. (2008). Teatralne mystetstvo na zakhidnoukrainskykh zemliakh u 1918 - 1939 rr. [The Theatrical Art in Western Ukrainian Lands in 1918 - 1939]. Studii mystetstvoznavchi. Teatr. Muzyka. Kino, 2 (22), 33-48. [in Ukrainian]

Buty chy ne buty (1936). Buty chy ne buty (Problema Volynskoho Ukrainskoho Teatru) [To Be or not to Be (Volyn Ukrainian Theater Problem)]. Ukrainska nyva, 18, 25 zhovtnia, 3. [in Ukrainian]

Davydiuk, R. (2016). Ukrainska politychna emihratsiia v Polshchi: sklad, struktura, hromadsko-politychni praktyky na terytorii Volynskoho voievodstva [Ukrainian Political Emigration in Poland: Composition, Structure, Socio-Political Practices in Volyn Region]. Lviv-Rivne: Diatlyk M., 704 p. [in Ukrainian]

Derzhavnyi arkhiv Ivano-Frankivskoi oblasti [State Archives of Ivano-Frankivsk region-SAIFR]

Derzhavnyi arkhiv Rivnenskoi oblasti [State Archives of Rivne region-SARR]

Derzhavnyi arkhiv Ternopilskoi oblasti [State Archives of Ternopil region-SATR]

Derzhavnyi arkhiv Volynskoi oblasti [State Archive of Volyn Region - SAVR]

Desiata richnytsia isnuvannia Ukrainskoho Naddniprianskoho Teatru u Polshchi [The Ukrainian Naddnipryanshchyna Theater $10^{\text {th }}$ Anniversary in Poland] (1932). Desiata richnytsia isnuvannia Ukrainskoho Naddniprianskoho Teatru u Polshchi. Tryzub, 25-26, 19 chervnia, 4. [in Ukrainian]

Ha (1922). Teatr "Vidrodzhennia" na Volyni [The "Vidrodzhennia" ("The Renaissance") Theater in Volyn]. Teatralne mystetstvo, III-IV, 15 chervnia, 22-23. [in Ukrainian]

Haluzevyi derzhavnyi arkhiv Sluzhby bezpeky Ukrainy, m. Rivne [Sectoral State Archive of the Security Service of Ukraine, Rivne - SSA SSU, Rivne]

Hastroli trupy Poltavchanka (1932). Hastroli trupy Poltavchanka [Poltavchanko's Theater Troupe Tours]. Ukrainska nyva, 4-5, 24 sichnia, 6. [in Ukrainian]

Konkurs dramatychnykh hurtkiv na Zdolbunivshchyni (1939). Konkurs dramatychnykh hurtkiv na Zdolbunivshchyni [Drama Circles Competition in Zdolbunivshchyna]. Volynske slovo, 20, 23 lypnia, 3. [in Ukrainian]

Kononiv, Yu. (1992). Nash teatr: knyha diiachiv ukrainskoho teatralnoho mystetstva: 1915 - 1991 [Our Theater. A Book of Ukrainian Theater Art Figures of 1915 - 1991]. Vol. 2. Niu-York; Paryzh; Sidnei; Toronto, 796 p. [in Ukrainian]

Luzhnytskyi, H. (Ed.) (1975). Ukrainskyi teatr pislia vyzvolnykh zmahan [Ukrainian Theater after the Liberation Competitions]. In Nash teatr: knyha diiachiv ukrainskoho teatralnoho mystetstva: 1915 - 1975. Vol. 1. Niu-York; Paryzh; Sidnei; Toronto, 847 p. [in Ukrainian]

Narizhnyi, S. (1942). Ukrainska emihratsiia: kulturna pratsia ukrainskoi emihratsii mizh dvoma svitovymy viinamy [The Ukrainian Emigration: the Cultural Work of Ukrainian Emigration between the two World Wars]. Part 1. Praha: Studii Muzeiu Vyzvolnoi Borotby Ukrainy, 327 p. [in Ukrainian] 
O. K. (1937). "Temna pliama" ["Dark Spot”] (retsenziia). Volynske slovo, 36, 12 hrudnia, 4. [in Ukrainian]

Pevnyi, M. (1936). Volynskyi Ukrainskyi Teatr [Volyn Ukrainian Theater]. Ukrainska nyva, 13, 13 veresnia, 2. [in Ukrainian]

Podorozh Volynskoho Ukrainskoho teatru po Volyni (1937). Podorozh Volynskoho Ukrainskoho teatru po Volyni [Volyn Ukrainian Theater Tour in Volyn region]. Volynske slovo, 22, 8 lypnia, 3. [in Ukrainian]

Samoorhanizatsiia ta hromadske zhyttia ukrainskoi emihratsii v Polshchi (1926). Samoorhanizatsiia ta hromadske zhyttia ukrainskoi emihratsii v Polshchi [Self-organization and the Public Life of the Ukrainian Emigration in Poland] (druha polovyna 1925 r. - 1 veresnia 1926 r.). Visti UTsK $v$ Polshchi, 7, Hruden, 13-14. [in Ukrainian]

Staryi teatral. (1929). Teatralni sylvetky [Theatrical Silhouettes]. Ukrainska nyva, 32, 13 serpnia, 3. [in Ukrainian]

Stepaniuk, S (2008). Diialnist Volynskoho ukrainskoho teatru (1928 - 1939) [Volyn Ukrainian Theater Activity (1928 - 1939)]. Ukraina: kulturna spadshchyna, natsionalna svidomist, derzhavnist, 17, 320-327. [in Ukrainian]

Volodymyrivshchyna (1928). Volodymyrivshchyna [Volodymyrivshchyna]. Dilo, 262, 24 lystopada, 4. [in Ukrainian]

Yuvilei artysta Berezovskoho (1935). Yuvilei artysta Berezovskoho [Artist Berezovskyi's Anniversary]. Ukrainska nyva, 27-28, 6 lypnia, 6. [in Ukrainian]

Zahalni zbory teatralnoho tovarystva (1939). Zahalni zbory teatralnoho tovarystva [The Theater Society General Meeting]. Volynske slovo, 4, 2 liutoho, 5. [in Ukrainian]

Zhyviuk, A. (2011). Za moskovskym chasom: kontroversii radianizatsii Rivnenshchyny (kinets 1930-kh-kinets 1950-kh rokiv) [Moscow Time: the Controversy over the Sovietization of Rivne region (late 1930-ies - late 1950-ies)]. Rivne: "Papirus-Druk", 186 p. [in Ukrainian]

The article was received on July 09, 2019. Article recommended for publishing 20/05/2020. 